Eastern European National University of Lesya Ukrainka, Department of Tourism and Hospitality Management, Lutsk city; ORCID ID 0000-0002-5395-7557, e-mail: Ierko@eenu.edu.ua

Anastasia Rudyk, Student,

Eastern European National University of Lesya Ukrainka, Lutsk city; ORCID ID 0000-0002-8554-305X, e-mail: runa19032001@gmail.com

https://doi.org/10.29038/2411-4014-2020-03-77-83

\title{
ECOLOGICAL MARKETING AS A TOOL OF STRATEGY OF HOTEL BUSINESS AND TOURISM DEVELOPMENT
}

The essence of the concept of ecological marketing is considered. Different approaches and views on the essence of the concept of "environmental marketing" are clarified. The role of ecological marketing for the development of hotel enterprises around the world is proved. The understanding of ecological marketing in relation to the tools of its application is outlined and their differences are established. The definition of ecological marketing of the hotel enterprise is given. An overview of the application of environmental marketing in the largest hotel chains in the world. Problems of ecological marketing and business development are analyzed.

Key words: ecological marketing, hotel economy, ecological branding, ecobranding, «green» marketing, Hilton, Marriot.

Ирина Ерко,

кандидат географических наук, доцент,

Восточноевропейский национальный университет имени Леси Украинки, кафедра туризма и гостиничного хозяйства,

Луцк

Анастасия Рудик,

студентка,

Восточноевропейский национальный университет имени Леси Украинки, Луцк

\section{ЭКОЛОГИЧЕСКИЙ МАРКЕТИНГ КАК ИНСТРУМЕНТ СТРАТЕГИИ РАЗВИТИЯ ГОСТИНИЧНОГО БИЗНЕСА И ТУРИЗМА}

В статье рассмотрена сущность понятия экологический маркетинг. Доказано, что экологический маркетинг приобретает все большее значение для развития гостиничных предприятий всего мира. Установлено, что понимание экологического маркетинга относительно применения его инструментов отличаются. Дано собственное определение экологического маркетинга гостиничного предприятия. Осуществлен обзор применения экологического маркетинга в крупнейших гостиничных сетях мира. Проанализированы проблемы развития экологического маркетинга и бизнеса.

Ключевые слова: экологический маркетинг, гостиничное хозяйство, экологический брендинг, екобрендинг, «зеленый» маркетинг, Hilton, Marriot.

Ірина Єрко, кандидат географічних наук, доцент, Східносвропейський національний університет імені Лесі Українки, кафедра туризму та готельного господарства, м. Луцьк 
Анастасія Рудик, студентка,

Східноєвропейський національний університет імені Лесі Українки, м. Луцьк

\title{
ЕКОЛОГІЧНИЙ МАРКЕТИНГ ЯК ІНСТРУМЕНТ СТРАТЕГІЇ РОЗВИТКУ ГОТЕЛЬНОГО БІЗНЕСУ ТА ТУРИЗМУ
}

\begin{abstract}
У статі з'ясовано, що поняття «зелений маркетинг» або екологічний маркетинг з'явилося в кінці 80-х років минулого століття. Зелений маркетинг - це маркетинг продуктів, які повинні бути екологічно безпечними. Тим не менш, визначення зеленого маркетингу часто відрізняються. Існує три погляди стосовно дефініції «зелений» маркетинг. Екорітейлинг - маркетинг продуктів, які вважаються екологічно безпечними. Соціальний маркетинг - розробка та реалізація продукції, покликаної мінімізувати негативний вплив на стан навколишнього середовища. Енвайронмент маркетинг стосується екології природного середовища. Це зусилля організації з виробництва, просування, пакування та повторного використання товарів таким чином, який відповідає екологічним проблемам.

Екологічний маркетинг готельного підприємства - це діяльність підприємства, спрямована на задоволення матеріальних і нематеріальних потреб споживача в період його перебування в готелі без нанесення шкоди навколишньому природному середовищу та формуванні позитивного сприйняття підприємства потенційними споживачами як екологічного.

Основними критеріями, яким повинен відповідати еко-готель є: використання для енергозабезпечення відновлюваних джерел енергії, таких як сонячна або енергії вітру; енергозберігаюче освітлення; рециркуляція стічних вод, які повторно використовуються кухнею, лазнею і пральнею, тощо. Обов'язковою умовою, яка служить для присвоєння готелю статусу “екологічний”, є сертифікація незалежною третьою стороною або державою, на території якої він знаходиться.

Потрібно заохочувати діяльність тих готелів, які справді намагаються екологізувати свою діяльність, а не використовують це як просто гасло. Для кращого розуміння споживачами екологічної сутності готелів доцільно ширше використовувати міжнародні стандарти, або створити свої.
\end{abstract}

Ключові слова: екологічний маркетинг, готельне господарство, екологічний брендинг, екобрендинг, «зелений» маркетинг, Hilton, Marriot.

Introdaction. Ecological "coloring" of any activity is now very popular. In various activities, entrepreneurs try to prove the environmental friendliness of their products or services, which has caused a significant variety of approaches and understandings. In various activities, environmental friendliness can be used as a marketing move to increase income, or a tribute to fashion, or it is a truly conscious activity. However, it is safe to say that in the absence of clear definitions, environmental orientation is really gaining momentum, like the philosophy of hospitality. Therefore, we chose this study to find out the role, nature, approaches and examples of environmental activities in the hotel industry.

Literature review. Among foreign scientists whose works address the problems of environmental marketing include such as I. Ansoff, G. Assel, F. Kotler, S. Minetti, M. Porter, X. Hershgen, as well as among domestic E. Adamov, O. Zozulov, N. Vinogradskaya, L. Grishko, T. Zaychuk, J. Ottaman, O. Danilova, I. Poginayko etc.

But environmental marketing in services, including hospitality, restaurants and tourism, have significant features. Therefore, this issue needs additional attention and analysis.

Problem statement and research objectives. The purpose of the study is to consider the features of the concept of environmental marketing. The main tasks are aimed at clarifying the nature and role of environmental marketing in the hotel industry.

Key results. The concept of "green marketing" or environmental marketing appeared in the late 80's of last century. The basis for environmental or "green" marketing are the concepts of socio-ethical marketing, which are based on meeting the needs of consumers and improving the welfare of society as a whole. Over the past few decades, humanity has begun to prioritize global well-being with an understanding of its impact on its own well-being. The first major influence was environmental movements, which drew the attention of marketers and the public to environmental issues. Activists believed that the goal of marketing should not be 
to meet individual needs by developing a wider range of products, but to improve the quality of life in general.

The main areas of action to protect the environment were: reduction of pollution, reuse of resources, waste collection and disposal.

This term describes the organization's efforts in designing, promoting, pricing, and distributing products that do not harm the environment. This has been defined as a process of management responsible for identifying, anticipating and meeting the needs of customers and society in a profitable and sustainable way. Green marketing is the marketing of products that must be environmentally friendly. However, definitions of green marketing often differ. There are three views on the definition of "green marketing":

Ecoretailing is the marketing of products that are considered environmentally friendly.

Social Marketing - development and sale of products designed to minimize the negative impact on the environment.

Environment Marketing refers to the ecology of the natural environment. This is the organization's efforts to produce, promote, package and reuse goods in a way that meets environmental concerns [1].

Different authors give different definitions of environmental marketing. The American Marketing Association (AMA) views "green" marketing as the development and sale of products that are considered environmentally safe (ie, designed to minimize the negative impact on the environment or to improve its quality).

This term can also be used to describe efforts to produce, promote, package and return products in a way that is consistent with environmental concerns [2].

Positioning firms themselves as "green" or environmental has a number of features. Often the idea of what is environmentally different differs between firms and their customers. So companies are using environmental or "green" marketing to expand sales rather than referring to actual environmental performance. Tiffany Gallicano [3] presented an integrated vision for analyzing the approach of firms in environmental marketing:

- business is essentially dirty, but it concerns environmental initiatives. The company contributes to environmental efforts or achievements that may divert attention from other environmental issues;

- the company claims that the product is green on the basis of several features, not taking into account the analysis of the full life cycle;

- the product may be "green", but distracts it from the impact on the environment of other categories of goods;

- environmental claims are made that cannot be substantiated by data or third party verification;

- environmental claims are inflated or exaggerated;

- consumers misunderstand the statements;

- statements contain confusing pseudo-scientific value;

- the company claims that the product or activity is "green", even if the laws restrict it;

- the company promotes "green" initiatives, lobbying against environmental laws and regulations;

- the company makes false statements;

- the company creates false third-party definitions or approvals, which do not exist;

- the company does not recognize the existence of an informed discussion.

According to V. Oksenyuk, environmental marketing is a managerial functional activity within the general management system of the enterprise, aimed at identifying, forecasting and meeting consumer needs so as not to disturb the ecological balance in the environment and not to harm human health [4].

$\mathrm{N}$. Zinovchuk and A. Rashchenko believe that environmental marketing is an economic activity of enterprises aimed at the production of environmentally friendly products, the formation of demand for these products, bringing all the resources of the enterprise in line with market requirements and capabilities to obtain products without application damage to the environment [5].

M. Belopolsky and T. Tolpezhnikova give their definition of environmental marketing, as the development and creation of methods for promoting and selling not only environmentally friendly products or services, but also the promotion of environmentally friendly production [6].

Marketing activities of modern enterprises are becoming more focused on the concept of eco-economic development, "environmental products" are becoming more relevant, and as a result, eco-branding 
(environmental marketing). Ecological goods and services, as a rule, are more ecological at the stage of consumption and provision in comparison with analogous goods, and are components of more ecological technological processes.

Ecological branding deals with the delineation of ecological properties of products and their positioning on the market. Ecological branding (ecobranding) - a type of branding, which is the activity of creating and implementing environmentally friendly brand in the market through marketing tools, technology management and advertising support of the brand with emphasis on environmental qualities of the product, based on forming a favorable image of consumer advertising brand, product, company and its allocation among others as a producer of "green" goods [7].

Ecological marketing in a hotel enterprise has a special specificity, because hotel enterprises are not engaged in the development of natural resources or the development of environmental services. On the other hand, they are engaged in meeting consumer demands for environmental protection, the introduction of environmental factors in their own promotion and marketing strategy, from which they receive additional income.

In our opinion, "ecological marketing of a hotel enterprise" is an activity of the enterprise aimed at meeting the tangible and intangible needs of the consumer during his stay in the hotel without harming the environment and forming a positive perception of the enterprise by potential consumers as ecological.

The hotel company must confirm its environmental orientation by implementing measures aimed at reducing the use of water resources, electricity, carbon emissions, recycling of organic waste and more.

O. Danilova, I. Poginayko propose the definition of an ecological hotel as "ecologically certified housing, which pursues the goal of improving the environment by minimizing its own negative impact on the environment."

The main criteria that an eco-hotel must meet are: the use of renewable energy sources, such as solar or wind energy, for energy supply; energy saving lighting; wastewater recycling, which is reused in the kitchen, bath and laundry, etc. Certification by an independent third party or the country in which it is located is a prerequisite for assigning the hotel "environmental" status.

In our opinion, the set of measures included in the strategy of development of the hotel enterprise must include the ecological orientation of the enterprise, which is a very important way of its development today. After all, with the rapid growth of public interest in the state of the global world environment, the demand for information about actions aimed at improving it is growing. That is why hotel companies should create a positive atmosphere of perception of their own brands, so that consumers at the subconscious level form an opinion about the brand as a positive factor influencing the environment.

We should not forget that this way of development will increase the income of the hotel business, for example, in particular through: saving water, energy and other resources, by increasing the number of potential consumers through the positive image of the hotel business in the media.

Attempts to introduce environmental certification and environmental labeling for the hotel and restaurant business are quite effective, it is an effective marketing tool. The basic document in the field of environmental voluntary certification was the environmental management standard ISO 14001 (EMS), which was adopted by the International Organization for Standardization (ISO). To obtain the status of an eco-hotel or eco-restaurant, compliance with this standard must be confirmed. Some countries have their own standards (for example, in the UK - BS 7750 Specification for Environmental Management Systems, in Canada - CAN / CSA Z750-94: Guidelines for an Environmental Management System, in the European Union - EMAS) [9].

Global hotel chains such as Hilton, Marriot use environmental marketing as an effective tool for hotel development and promotion strategy.

The Hilton hotel chain has been pursuing an environmentally friendly course since 2008. In 2019, the intensity of carbon emissions decreased by $36 \%$, and by 2030 it is planned to improve to $61 \%$. Waste decreased by $41 \%$, energy intensity by $24 \%$ and water use by $20 \%$, saving more than 1 billion US dollars. Hilton has developed its own platform for calculating and analyzing the environmental and social impact of each Hilton Worldwide hotel - LightStay, which is now Hilton Worldwide's own platform for measuring the effectiveness of corporate responsibility. The platform measures energy consumption, water use, waste and carbon emissions at every Hilton Worldwide hotel around the world. LightStay has allowed each Hilton 
hotel to be certified according to the ISO 14001 environmental management standard and the ISO 50001 energy management standard.

Hilton Worldwide $є$ першим готельним брендом, що увійшов до складу об'єднання компаній Science Based Targets 3 метою встановлення цілей скорочення викидів вуглецю, передбачених Паризькою кліматичною угодою. Також став першою готельною компанією у світі, що підписала продовольчу обіцянку World Resource Institute, зобов'язуючись зменшити відходи, пов'язані 3 харчовими продуктами, рекламуючи страви в меню, виготовлені на основі рослин.

At the end of 2019, more than 1,700 hotels of the brand have installed a smart irrigation system, or drip irrigation system. Thanks to the LightStay platform created by the network, in 2019 it was possible to reduce food waste by $60 \%$ in 6 hotels of the chain in Egypt in the Middle East, at the same time when 860 hotels implemented waste composting programs. All these actions, in the first place, bring additional income to the company.

Hilton was the first to recycle soap waste. The chain operates the largest soap processing program in the industry, and in 2019 expanded its soap processing program to 5,300 hotels ( $88 \%$ of the portfolio). Used soap from the guest rooms is collected by employees and sent for recycling, and then the recycled soap is donated to charity [10].

Many hotel chains around the world use solar panels. The use of solar panels today is one of the most important ways to conduct environmental marketing and, at the same time, save money.

In our opinion, donations as a charitable activity of hotels are an effective tool to increase their popularity among consumers. Today, the media use every opportunity to publish data on charitable work of both individuals and businesses, because this information is interesting and always relevant to readers. On the other hand, for the company it is a great opportunity to increase the number of potential consumers, and in the case of a hotel company - potential hotel guests.

The brand has removed plastic water bottles from all meetings and events in hotels on the Asian Pacific coast, Europe, the Middle East and Africa. A global ban on plastic straws, cocktail skewers and chopsticks has been introduced.

The Honors App, which acts as an electronic key to the room, reduces the need for plastic key cards.

In the last year, 1,100 hotels in the chain have replaced incandescent lamps with more energy-efficient LED lamps, as they consume 10 times less electricity and do not contain mercury. It is also worth noting that this replacement is currently one of the most relevant trends in environmental marketing in the world [11].

The hotel chain Marriot International in 2017 collected more than 150 thousand $\mathrm{kg}$ of waste, distributed to charity more than 100 thousand recycled soap bars, recycled 46 thousand $\mathrm{kg}$ of plastic.

The company has partnered with Repeat Roses ${ }^{\circledR}$, so that after major events, all flowers are recycled and delivered to local organizations, including hospices, nursing homes and cancer centers, instead of ending up in landfills. After reusing the flowers, the company recycles them into fertilizer.

One of the goals of the Marriott network is to reduce waste by one hotel room by $45 \%$ from 2016 to 2025. Since 2004, Marriott has been working with Arrow Sustainable Technology Solutions to ensure managed and franchised facilities around the world are safe and environmentally friendly and clean electronic waste maintenance option. In 2017, Marriott helped transport 20,450 kg of e-waste from landfills. More than 3,137 electric car charging stations (EVs) are available and ready for use in Marriott hotels.

The International Organization of Hotel and Restaurant Associations (International HO-RE-CA) also promotes the hotel industry through environmental advice; study of ways to combat smoking in hotels, restaurants and cafes, etc. Also, hotels that position themselves with ecotourism will have a significant prospect of development, and in this specialization the western territories of Ukraine are attractive [12].

Conclusions and future research prospects. Environmental marketing is a powerful stimulator of revenue growth of the hotel business and, at the same time, allows them to turn environmental orientation into the philosophy and goals of their business. Thanks to modern technologies, this creates additional income and has a significant environmental and social effect. However, the variety of approaches, forms and tools used in environmental marketing creates difficulties in perceiving the truth of the intentions of hotels. It is necessary to encourage the activities of those hotels that are really trying to green their activities, rather than using it as a simple slogan. To do this, it is advisable to create certain standards that will help the 
consumer to determine which hotel is really environmentally friendly. You can use international standards, or you can create your own standards. In Ukraine, there are tourist and hotel associations that could develop this area of activity.

\section{Sources and literature}

1. Green Marketing in Hospitality Industry Mohammadreza Ashrafi. Journal of Applied Environmental and Biological Sciences URL: https://www.textroad.com/pdf/JAEBS/J.\%20Appl.\%20Environ.\% (Дата звернення : 3.04.2020).

2. AMA URL: https://www.ama.org/the-definition-of-marketing- (Дата звернення : 15.04.2020).

3. T. Gallicano. A CRITICAL ANALYSIS OF GREENWASHING CLAIMS - Public Relations Journal - Vol. 5, No. 3, 2011.

4. Оксенюк Б. Екологічний маркетинг: необхідність виникнення, поняття, характеристика URL:http://elartu.tntu.edu.ua/bitstream/lib/21169/2/SEIED_2017_Oksentyuk_B-Environmental_marketing_55-57.pdf (Дата звернення : 1.04.2020).

5. Зіновчук Н.В., Ращенко А.В. Екологічний маркетинг : навчальний посібник. - Житомир. Видавництво ЖДУ ім. І.Франка. - 2015. - 190 с.

6. Белопольський М. Г., Толпежнікова Т. Г. Система екологічного маркетингу промислових підприємств. URL:http://eir.pstu.edu/bitstream/handle/123456 (Дата звернення : 19.04.2020).

7. С.М. Махнуша, Н.Є. Косолап. Маркетинг інновацій та екологічний брендинг: аналіз зв'язку. Маркетинг i менеджмент інноваиій, 2011, № 1. URL:https://mmi.fem.sumdu.edu.ua/sites/default/files/mmi2011_1_3 (Дата звернення : 19.03.2020).

8. Данілова О.М., Погинайко І.В. Еко-маркетингові тенденції в розвитку готельного господарства / Науковий вісник Чернівеиького університету URL:file:///E:/MyDocuments/Downloads/Nvchnu_2012_633-38.pdf (Дата звернення : 20.05.2020).

9. ISO STANDARDS URL: https://www.iso.org/iso-14001-environmental-management.html (Дата звернення : 3.04.2020).

10. Хілтон https://www.hilton.com/ (Дата звернення : 3.05.2020).

11. Тренд на турботу про екології: хто використовує це в маркетингу URL:https://koloro.ua/ua/blog/brending-i-marketing/trend-na-botu-.html (Дата звернення : 10.05.2020).

12. Н. Рудик, А. Рудик, Н. Моклиця. Розвиток готельного господарства в Україні. Economics\&Development. - №1(2), - 2019. - C. 22-31.

\section{References}

1. Green Marketing in Hospitality Industry Mohammadreza Ashrafi. Journal of Applied Environmental and Biological Sciences. URL: https://www.textroad.com/pdf/JAEBS/J.\%20Appl.\%20Environ.\% [In English].

2. AMA URL: https://www.ama.org/the-definition-of-marketing- [In English].

3. T. Gallicano. A CRITICAL ANALYSIS OF GREENWASHING CLAIMS - Public Relations Journal - Vol. 5, No. 3, 2011.

4. Okseniuk B. Ekolohichnyi marketynh: neobkhidnist vynyknennia, poniattia, kharakterystyka [Environmental marketing: the need, the concept, characteristics] URL:http://elartu.tntu.edu.ua/bitstream/lib/21169/2/SEIED_2017_Oksentyuk_B-Environmental_marketing_55-57.pdf [In Ukrainian].

5. Zinovchuk N.V., Rashchenko A.V. Ekolohichnyi marketynh : navchalnyi posibnyk. [Environmental marketing: a textbook] - Zhytomyr. Vydavnytstvo ZhDU im. I.Franka. - 2015. - $190 \mathrm{~s}$.

6. Belopolskyi M. H., Tolpezhnikova T. H. Systema ekolohichnoho marketynhu promyslovykh pidpryiemstv. [The system of ecological marketing of industrial enterprises] URL: http://eir.pstu.edu/bitstream/handle/123456 [In Ukrainian].

7. S.M. Makhnusha, N.Ie. Kosolap. Marketynh innovatsii ta ekolohichnyi brendynh: analiz zviazku. [Innovation Marketing and Environmental Branding: A Relationship Analysis] Marketynh i menedzhment innovatsii, 2011, № 1. URL: https://mmi.fem.sumdu.edu.ua/sites/default/files/mmi2011_1_3 [In Ukrainian].

8. Danilova O.M., Pohynaiko I.V. Eko-marketynhovi tendentsii v rozvytku hotelnoho hospodarstva [Ecomarketing trends in the development of the hotel industry] / Naukovyi visnyk Chernivetskoho universytetu URL: file:///E:/MyDocuments/Downloads/Nvchnu_2012_633-38.pdf [In Ukrainian].

9. ISO STANDARDS URL: https://www.iso.org/iso-14001-environmental-management.html [In English].

10. Khilton URL: https://www.hilton.com/ [In English]. 
11. Trend na turbotu pro ekolohii: khto vykorystovuie tse $\mathrm{v}$ marketynhu. [The trend to care about the environment: who uses it in marketing] URL: https://koloro.ua/ua/blog/brending-i-marketing/trend-na-botu-.html [In Ukrainian].

12. N. Rudyk, A. Rudyk, N. Moklytsia. Rozvytok hotelnoho hospodarstva v Ukrain / Economics\&Development. - №1(2), - 2019. - S. 22-31.

Стаття надійшла до редакції 31.05.2020 р. 